\title{
STUDIES OF BLOOD VOLUME IN THE TETRALOGY OF FALLOT AND IN OTHER TYPES OF CONGENITAL HEART DISEASE ${ }^{1}$
}

\author{
By WOODROW NELSON, H. S. MAYERSON, JOHN H. CLARK, AND \\ CHAMP LYONS \\ (From the Departments of Physiology and Surgery, School of Medicine, Tulane University of \\ Louisiana, New Orleans)
}

(Received for publication January 20, 1947)

The recent introduction by Blalock (1) of an operative procedure for the successful treatment of the tetralogy of Fallot has focused considerable attention on the various manifestations of this condition. It has also indicated the need of more information to aid in the diagnosis and prognosis, as well as in the preoperative and postoperative treatment of the patients with this disease. The present study is concerned particularly with the measurement of blood volume, hemoglobin, and plasma protein in 7 cases of tetralogy of Fallot, 4 cases of isolated septal defect, and 1 case each of Eisenmenger complex, isolated pulmonic stenosis, coarctation of the aorta, congenital mitral stenosis, and patent ductus arteriosus.

Fallot (2), in 1888, described the complex of combined congenital cardiac defects of pulmonic stenosis, right ventricular hypertrophy, patent interventricular septal defects, and dextroposition of the aorta which is commonly referred to as the "Tetralogy of Fallot." It is a common congenital defect of the heart. It constitutes 77 per cent of the 110 cases of pulmonary stenosis and 66 per cent of 40 cases of pulmonary atresia in Abbott's (3) series of 1,000 cases. The Eisenmenger complex is much less common. It differs from Fallot's tetralogy by having no pulmonary stenosis or atresia. The prognosis is somewhat better, the average life span being 16 years compared to 12.5 years in Fallot's type (4). The oldest age of survival recorded in either type is 60 years (5).

The principal extracardiac pathology of Fallot's tetralogy is a generalized vascular distention, capillary hyperplasia (3), and increased tortuosity. This is accompanied by polycythemia and increased blood viscosity. Blood arteriovenous-oxygen difference is increased, and its per cent oxygen

1 One of series of studies being conducted under a grant from the Research and Development Division, Office of the Surgeon General, United States Army. saturation is decreased. Cyanosis, usually present at rest, is increased on exertion, when dyspnea also appears.

Although the elevated values of hemoglobin and hematocrit in the tetralogy of Fallot suggest an increased blood volume, measurements of blood volume have been recorded in relatively few cases of this disease. Meyer (6) measured the volume in 1 case using congo red, as did Blumenfeldt and Wollheim (7) using trypan blue. Both authors reported extremely low values for plasma volumes. Weber and Dorner (8), using the carbon monoxide method, obtained a value of $131 \mathrm{ml}$. per $\mathrm{kgm}$. or a total blood volume of $6,040 \mathrm{ml}$. in a patient with cyanotic congenital heart disease (morbus caeruleus) as compared with the value of $77 \mathrm{ml}$. per $\mathrm{kgm}$. in normal individuals measured by their method. Hallock (9) used the T-1824 blue dye in studying 2 cases. He found low plasma volumes (29.9 and $29.3 \mathrm{ml}$. per $\mathrm{kgm}$.) and high cell volumes (144 and $77 \mathrm{ml}$. per kgm.).

\section{METHODS AND PROCEDURE}

Considerable care was devoted to the standardization of the procedures and methods used. All patients were studied under basal conditions. Breakfast was omitted, and the patients rested quietly in the recumbent position for at least 10 minutes before the determinations were made. Blood was drawn from an antecubital vein into syringes coated with a thin film of heparin. Total circulating plasma volume was determined by the method of Gregersen (10) using the Klett-Summerson photoelectric colorimeter. The amount of heparin which was used did not interfere with accurate determination of the plasma volume. To rule out the question of possible inadequate mixing because of slowed circulation, several successive samples were taken at 5-minute intervals after the usual 10-minute sample. In a number of cases, simultaneous samples were taken from the dorsal foot vein and an antecubital vein. All of our cases showed complete mixing in 10 minutes, and there was no evidence that the disappearance curve of the dye differed from that given for "normal" individuals. All adults were injected with 5 
ml. of dye. Children were given a smaller amount of dye roughly proportional to their normal weight.

Hematocrit values were obtained by centrifuging blood in Wintrobe tubes. Since spinning for 30 minutes at 3,000 revolutions per minute gave the same results as spinning for an hour, the former interval was used in all of the experiments. Hematocrit determinations were made on the samples of blood taken before and after the injection of the dye. This served as a check on possible fluid shifts during the 10-minute intervening period.

Red cell volumes were calculated from the hematocrit values. The absolute accuracy of this procedure has been questioned by some (11) and affirmed by others (12). The suggested discrepancy between the true red cell volume and that calculated from the hematocrit, if present, would tend to make our absolute values uniformly too high by a maximum of about 25 per cent. It would have less bearing on the relationship of the actual values to standard values obtained by the same procedure.
Hemoglobin was determined as oxyhemoglobin, using the photoelectric colorimetric method of Evelyn (13). Oxygen capacity determination by the Van Slyke-Neill method furnished the necessary constants for calculation of the actual values. Specific gravity of the plasma was determined by the falling-drop method (14), and plasma protein levels were calculated from these values by the formula of Weech, Reeves, and Goettsch (15). All readings were made as soon as possible after the blood was drawn. A series of determinations made at intervals on 9 "normal" subjects over a period of 4 months showed fluctuations of not more than 10 per cent. Changes of greater magnitude have therefore been considered as significant.

The values given by Gregersen (10) were used to assign standard levels in the adult patients for blood volume, plasma volume, red cell volume, total plasma protein, and total circulating hemoglobin. These values were assembled by Gregersen from a large series and agree in

TABLE I

Tetralogy of Fallot

\begin{tabular}{|c|c|c|c|c|c|c|c|c|c|c|c|c|}
\hline $\begin{array}{l}\text { Patient } \\
\text { number }\end{array}$ & Age & $\begin{array}{l}\text { Obs. } \\
\text { wt. }\end{array}$ & $\begin{array}{l}\text { Date } \\
1946\end{array}$ & Het. & Hb. & Hb. & $\begin{array}{l}\text { Plasma } \\
\text { protein }\end{array}$ & $\begin{array}{l}\text { Plasma } \\
\text { protein }\end{array}$ & $\begin{array}{l}\text { Plasma } \\
\text { volume }\end{array}$ & $\begin{array}{l}\text { Red cell } \\
\text { volume }\end{array}$ & $\underset{\substack{\text { Blood } \\
\text { volume }}}{x}$ & Comments \\
\hline & & kgm. & & $\begin{array}{c}\text { per } \\
\text { cent }\end{array}$ & $\begin{array}{l}\text { grams } \\
\text { per } \\
\text { cent }\end{array}$ & $\begin{array}{c}\text { grams } \\
\text { per } \\
\text { kgm. }\end{array}$ & $\begin{array}{c}\text { grams } \\
\text { per } \\
\text { cent }\end{array}$ & $\begin{array}{c}\text { grams } \\
\text { per } \\
k g m .\end{array}$ & \multicolumn{3}{|c|}{ ml. per kgm. } & \multirow{6}{*}{$\begin{array}{l}12 \text { pounds under average } \\
\text { weight }\end{array}$} \\
\hline 204 & 19 mos. & 6.8 & $7-9$ & 60 & 14.3 & 28.7 & 6.09 & 4.9 & 80.3 & 120.5 & 201.7 & \\
\hline \multirow[t]{7}{*}{208} & 22 yrs. & 57.6 & $1-31$ & 76 & 19.7 & 51.5 & 8.05 & $\cdot 5.1$ & 64.1 & 195.6 & 259.7 & \\
\hline & & 57.6 & $2-12$ & 70 & 20.7 & 40.0 & 6.85 & 4.0 & 57.8 & 135.1 & 193.1 & \\
\hline & & 54.9 & $3-12$ & 68 & 20.2 & 32.0 & 6.85 & 3.3 & 48.5 & 109.8 & 158.3 & \\
\hline & & 57.6 & $3-26$ & 59 & 17.2 & 18.9 & 5.88 & 2.6 & 44.8 & 64.6 & 109.5 & \\
\hline & & 57.6 & $5-9$ & 64 & 16.6 & 24.9 & 6.99 & 3.3 & 54.0 & 95.9 & 149.9 & \multirow{2}{*}{$\begin{array}{l}\text { Blalock procedure } \\
7-30-46\end{array}$} \\
\hline & & 58.1 & $7-18$ & 66 & 20 & 25.3 & 7.06 & 3.0 & 43.0 & 83.5 & 126.5 & \\
\hline & & 57.6 & $7-29$ & 70 & 20.3 & 23.2 & 6.68 & 2.3 & 34.3 & 80.0 & 114.3 & Died 8-1-46 \\
\hline 207 & 20 yts. & 49.0 & $3-28$ & 70 & 19.8 & 33.6 & 7.34 & 4.0 & 54.0 & 126.0 & 180.0 & Died 4-9-46. Autopsy \\
\hline \multirow[t]{2}{*}{205} & 4 yrs. & 15.9 & $4-30$ & 75 & 19.5 & 45.8 & 7.69 & 4.0 & 51.4 & 154.1 & 205.7 & \multirow{4}{*}{$\begin{array}{l}18 \text { pounds under usual weight } \\
\text { Neoplastic cachexia develop } \\
\text { ing symptom from carci- } \\
\text { noma of stomach }\end{array}$} \\
\hline & & 18.1 & $7-29$ & 70 & 20.5 & 21.9 & 6.99 & 2.4 & 32.0 & 74.9 & 106.9 & \\
\hline 206 & 44 yrs. & 46.3 & $5-7$ & 66 & 19.6 & 31.0 & 5.81 & 3.1 & 54.0 & 104.9 & 158.9 & \\
\hline & & 44.5 & $6-18$ & 65 & 19.6 & 33.5 & 5.39 & 3.2 & 59.8 & 111.0 & 170.8 & \\
\hline \multirow{3}{*}{212} & & 44.5 & $7-5$ & 63 & 18.5 & 24.5 & 6.37 & 3.1 & 49.0 & 83.4 & 123.4 & Died 7-31-46. Autopsy \\
\hline & 6 yrs. & 13.7 & $7-29$ & 81 & 20.5 & 63.1 & 6.41 & 3.7 & 58.4 & 294.3 & 307.7 & \multirow{7}{*}{$\begin{array}{l}15 \text { pounds under average } \\
\text { weight with marked mental } \\
\text { deficiency } \\
15 \text { pounds under average } \\
\text { weight } \\
\text { Blalock procedure } \\
7-20-46\end{array}$} \\
\hline & & 13.7 & $8-15$ & 81 & 21.8 & 93.4 & 6.16 & 5.0 & 81.4 & 346.9 & 428.3 & \\
\hline \multirow[t]{5}{*}{211} & $6 \mathrm{yrs}$. & 14.1 & $6-20$ & 73 & 21.4 & 44.9 & 6.65 & 3.8 & 56.7 & 153.2 & 209.9 & \\
\hline & & 14.1 & $6-29$ & 74 & 20.1 & 52.6 & 7.30 & 5.0 & 68.1 & 193.6 & 261.7 & \\
\hline & & 14.1 & 8-7 & 62 & 16.2 & 24.8 & 7.09 & 4.1 & 58.2 & 94.9 & 153.2 & \\
\hline & & 14.1 & $8-15$ & 59 & 17.3 & 17.8 & 4.80 & 2.0 & 42.1 & 60.4 & 102.8 & \\
\hline & & 14.1 & $9-10$ & 61 & 19.2 & 22.1 & 6.9 & 3.1 & 44.8 & 70.1 & 115.0 & \\
\hline
\end{tabular}


general with our findings and with those of other series (16). Standard values for blood, plasma, and red cell volumes in the children were calculated from the data given by Brines, Gibson, and Kunkel (17). Wintrobe's standard values were used for hemoglobin and hematocrit (18). Since all of our children were over 18 months old, their standard plasma protein level was assumed to be similar to that of the adult, i.e., 6.5 grams per cent.

Diagnosis of tetralogy of Fallot was made principally on a basis of : (1) a history of cyanosis since, or shortly after, birth; (2) physical findings of a pulmonic stenosistype murmur, cyanosis, finger and toe clubbing, and watchcrystal nail changes; and (3) X-ray findings of decreased conus pulmonus prominence. Retarded physical development was prominent in all of the children studied, and retarded mental development was observed in 1 case. Associated congenital defects were noted in 1 case. Rest cyanosis was present to a greater or lesser degree in all cases, and its presence in the absence of dyspnea and tachycardia was striking. Congestive failure was found in only 1 case (No. 206), and only 1 case (No. 212) showed marked cardiac enlargement. Right axis deviation was consistently found electrocardiographically. Circulation times, intracardiac diodrast studies, and oxygen analyses were done on some of the cases and showed markedly reduced arm-to-tongue or -face circulation time, right ventricle retention and right-to-left heart shunt, and decreased arterial oxygen saturation and increased arteriovenous oxygen difference. The aortic arch was on the left side in all cases. Two of the cases (Nos. 206 and 207) came to autopsy and presented the typical picture of the tetralogy of Fallot.

Case No. 210 was classified as an example of the Eisenmenger complex mainly on the basis of a prominent conus, lack of aortic prominence, and lack of a murmur typical of pulmonic stenosis. Since it was not feasible to employ venous catheterization, the possibility of an isolated inter-arterial septal defect was not definitely excluded. This patient manifested cyanosis only on exertion. The patient with isolated pulmonic stenosis showed a markedly prolonged retention of diodrast in the right ventricle and no evidence of septal defect. The diagnosis of patent interventricular septal defect was based primarily on the history and character of the murmur.

\section{RESULTS}

A total of 22 sets of determinations was done in the 7 cases of tetralogy of Fallot, 2 sets of determinations each in the case of the Eisenmenger complex and in the case of coarctation of the aorta. Single sets of determinations only were obtained in the cases of septal defect, congenital mitral stenosis, patent ductus arteriosus, and in isolated pulmonic stenosis.

TABLE II

Miscellaneous Congenital Heart Disease

\begin{tabular}{|c|c|c|c|c|c|c|c|c|c|c|c|c|c|}
\hline $\begin{array}{l}\text { Case } \\
\text { No. }\end{array}$ & Diagnosis & Age & $\begin{array}{l}\text { Obs. } \\
\text { wt. }\end{array}$ & $\begin{array}{l}\text { Date } \\
1946\end{array}$ & Het. & $\begin{array}{l}\text { Hemo- } \\
\text { globin }\end{array}$ & Hb. & $\begin{array}{l}\text { Plasma } \\
\text { protein }\end{array}$ & $\begin{array}{l}\text { Plasma } \\
\text { protein }\end{array}$ & $\begin{array}{l}\text { Plasma } \\
\text { volume }\end{array}$ & $\begin{array}{c}\text { Cell } \\
\text { volume }\end{array}$ & $\begin{array}{l}\text { Blood } \\
\text { volume }\end{array}$ & Comments \\
\hline 209 & $\begin{array}{l}\text { Isolated pul- } \\
\text { monic stenosis }\end{array}$ & 22 yrs. & $\begin{array}{l}\text { kgm. } \\
57.7\end{array}$ & $5-21$ & $\begin{array}{c}\text { per } \\
\text { cent } \\
62\end{array}$ & $\begin{array}{c}\text { grams } \\
\text { per } \\
100 \mathrm{ml} . \\
18.0\end{array}$ & $\begin{array}{c}\text { grams } \\
\text { per } \\
\text { kgm. } \\
20.9\end{array}$ & $\begin{array}{c}\text { grams } \\
\text { per } \\
\text { cent } \\
6.40\end{array}$ & $\begin{array}{c}\text { grams } \\
\text { per } \\
\text { kgm. } \\
2.8\end{array}$ & \multicolumn{2}{|c|}{ ml. per kgm. } & 115.9 & \\
\hline 210 & $\begin{array}{l}\text { Eisenmenger } \\
\text { complex }\end{array}$ & 16 yrs. & 47.6 & $5-31$ & 49 & 14.9 & 12.6 & 7.65 & 3.86 & 50.4 & 48.4 & 98.8 & \\
\hline 214 & $\begin{array}{l}\text { Coarctation of } \\
\text { aorta }\end{array}$ & 20 yrs. & 47.2 & $6-6$ & 44 & 13.1 & 11.1 & 7.27 & 3.43 & 47.4 & 37.2 & 84.5 & \\
\hline & & & 47.2 & $6-20$ & 38 & 11.6 & 9.4 & 6.68 & 3.37 & 50.4 & 39.0 & 81.4 & Ind \\
\hline 213 & $\begin{array}{l}\text { Patent ductus } \\
\text { arteriosus }\end{array}$ & 9 yrs. & 20.0 & $7-27$ & 38 & 13.3 & 14.5 & 7.44 & 5.95 & $7 \cdot 9.8$ & 48.8 & 128.5 & $\begin{array}{l}\text { No cardiac de- } \\
\text { composition }\end{array}$ \\
\hline 215 & $\begin{array}{l}\text { Congenital mi- } \\
\text { tral stenosis }\end{array}$ & 22 mos. & 10.4 & $8-13$ & 37 & 11.0 & 19.0 & 6.68 & 7.31 & 109.0 & 63.9 & 172.7 & $\begin{array}{l}\text { In congestive } \\
\text { failure }\end{array}$ \\
\hline 220 & $\begin{array}{l}\text { I.V. septal } \\
\text { defect }\end{array}$ & 5 yrs. & 18.1 & $9-26$ & 39 & 12.4 & 11.2 & 6.58 & 3.59 & 54.9 & 35.1 & 89.9 & \\
\hline 221 & $\begin{array}{l}\text { I.V. septal } \\
\text { defect }\end{array}$ & 5 yrs. & 16.3 & $9-24$ & 28 & 8.7 & 7.0 & 7.34 & 4.23 & 57.8 & 22.5 & 80.2 & \\
\hline 222 & $\begin{array}{l}\text { I.V. septal } \\
\text { defect }\end{array}$ & 5 yrs. & 16.3 & $9-24$ & 34 & 10.8 & 9.7 & 7.37 & 4.36 & 59.0 & 30.4 & 89.6 & \\
\hline 223 & $\begin{array}{l}\text { I.V. septal } \\
\text { defect }\end{array}$ & 10 yrs. & 27.2 & $10-1$ & 36 & 11.8 & 4.9 & 7.52 & 3.12 & 41.7 & 23.4 & 65.1 & \\
\hline
\end{tabular}




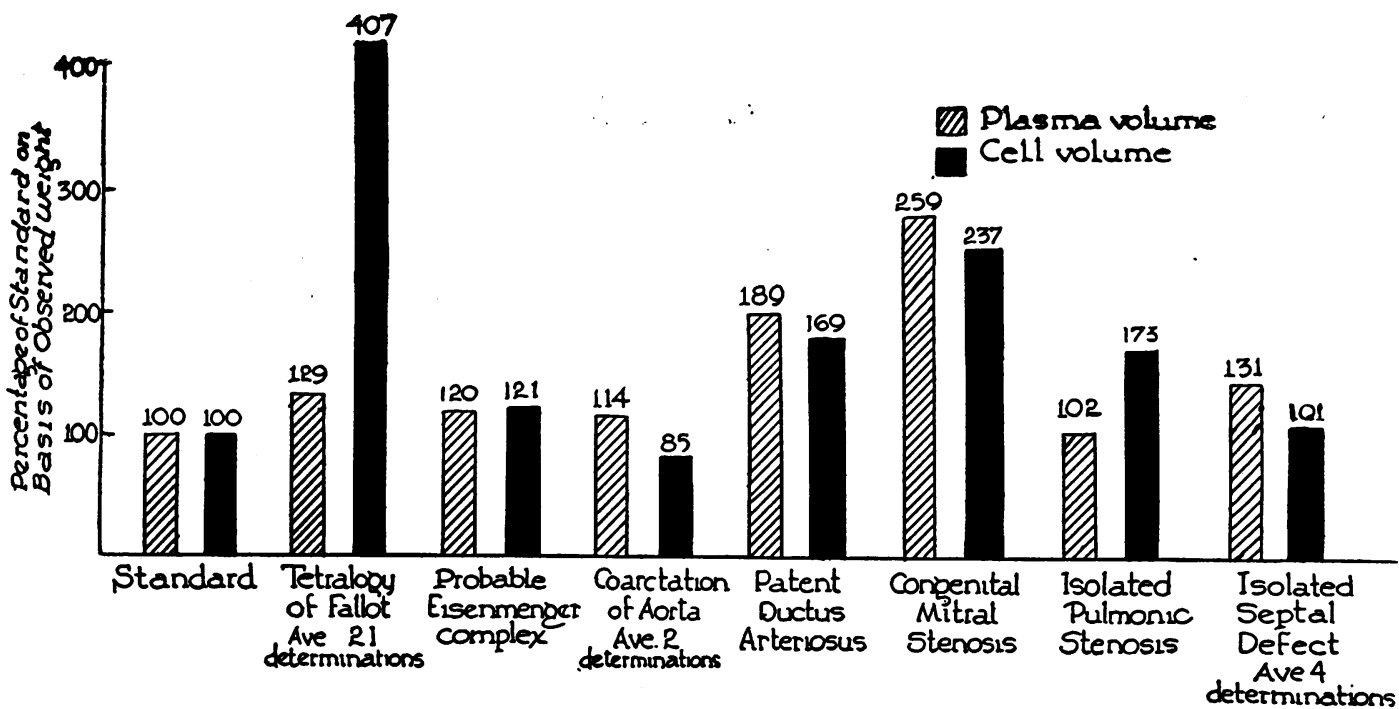

Fig. 1. Comparison of Tetralogy of Fallot with Other Types of Congenital Heart Disease

The results are given in detail in Tables I and II. A comparison of the plasma and red cell volumes in the various conditions is given in Figure 1. Our findings, contrary to those of previous investigators, indicate that the plasma volume is not significantly or consistently reduced in the tetralogy of Fallot.

The highest value for the total blood volume was $14,900 \mathrm{ml}$. (259 ml. per $\mathrm{kgm}$.) found in the first determination in Case 208. To our knowledge, this is the largest blood volume reported in this disease, although Hallock (9) reported a case of polycythemia vera with a blood volume of over 18 liters. This case (No. 208) is of additional interest because of the dramatic response to bed rest, the blood volume dropping progressively from over $14,900 \mathrm{ml}$. to $6,300 \mathrm{ml}$. in a period of 2 months (Figure 2). This occurred without any

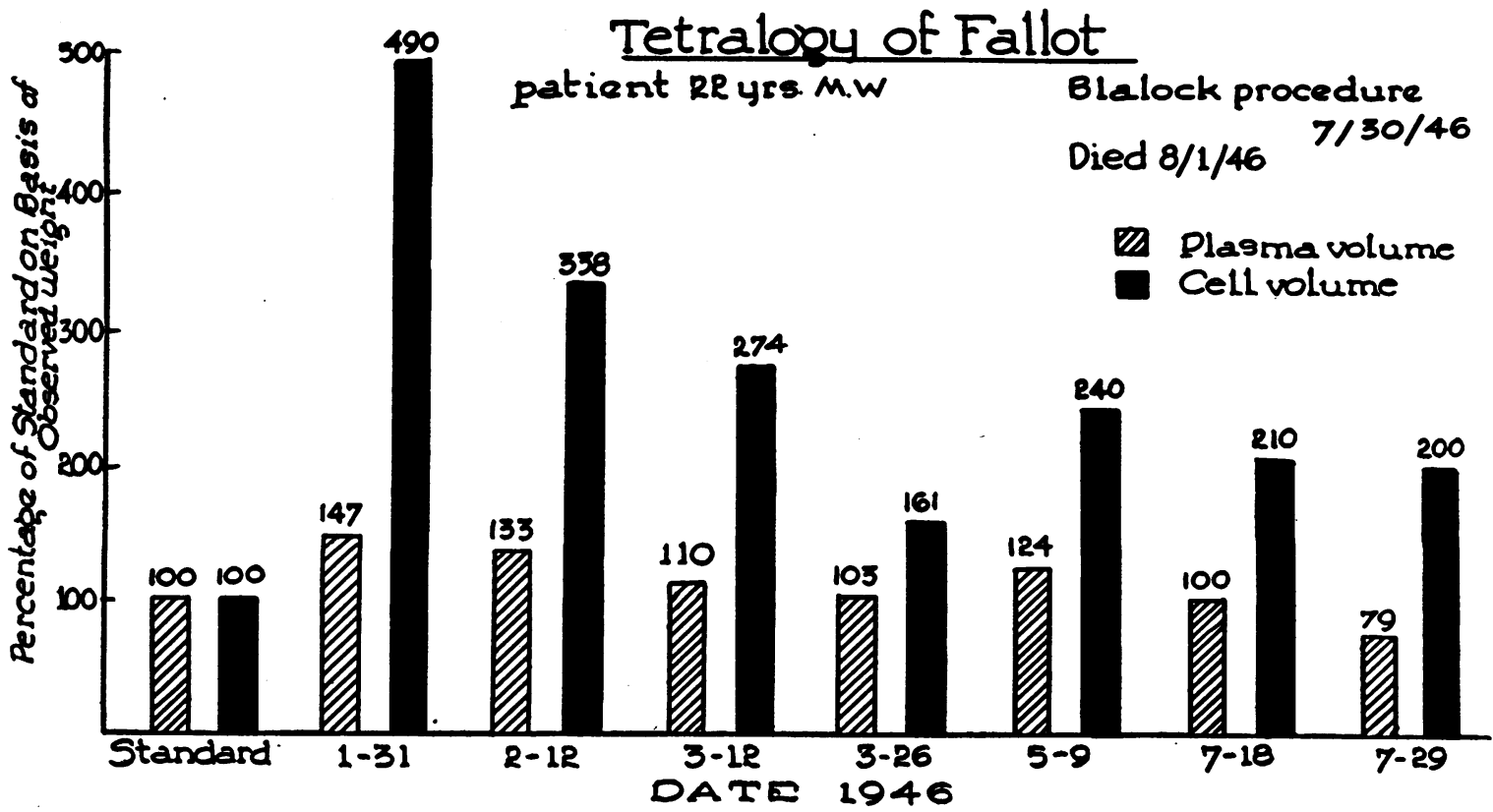

Fig. 2. Sertal Determinations of Plasma and Cell Volumes in a Patient 22 Years of Age (M. W.) with TETRALOGY OF FaLLOT 
hemorrhage and without clinical evidence of hemolysis. This decrease, while primarily due to a drop in the red cell volume, was accompanied by a drop in the plasma volume and total protein. This same tendency is also seen in Case 205, although the number of observations in this case is limited.

The highest total blood volume per kilogram was seen in Case 212. This child showed the most severe clinical picture of those surviving in the group. He manifested maximum cyanosis, exertional dyspnea, and cardiac enlargement. His initial blood volume was $4,215 \mathrm{ml}$. (307.7 ml. per $\mathrm{kgm}$.), and a second determination some 2 weeks later showed a value of $5,268 \mathrm{ml}$. (428. $3 \mathrm{ml}$. per kgm.).

Initial values for plasma volume ranged from 51.4 to $80.3 \mathrm{ml}$. per $\mathrm{kgm}$. These are 20 to 92 per cent above standard level as based on the patient's observed weights. Five of the patients were underweight at the time they were studied. We have found that in such individuals, plasma and cell volumes are more accurately predictable on the basis of optimal or usual weight. When the initial plasma volumes are calculated on this basis, the values in 4 of the 7 cases are almost exactly equal to the predicted or standard values. The remaining 3 cases (Nos. 204, 205, and 208) show values 111,121 , and 147 per cent, respectively, of the predicted levels. On the other hand, all of the patients showed strikingly increased cell volumes which varied from 104.9 to $294.3 \mathrm{ml}$. per $\mathrm{kgm}$. These values are from 269 to 998 per cent of standard on an observed weight, and 220 to 639 per cent on an optimal or usual weight basis. Calculation of the total circulating hemoglobin revealed high values consistent with the elevated total cell volume. The initial values varied from 28.7 grams per $\mathrm{kgm}$. to 63.1 grams per $\mathrm{kgm}$. and represented levels which were from 242 to 764 per cent of the standard on an observed, and 208 to 527 per cent on an optimal or usual, weight basis.

Two of the cases of tetralogy (Nos. 208 and 211) were operated upon (see case reports). Case 208 survived only 3 days, while Case 211 has

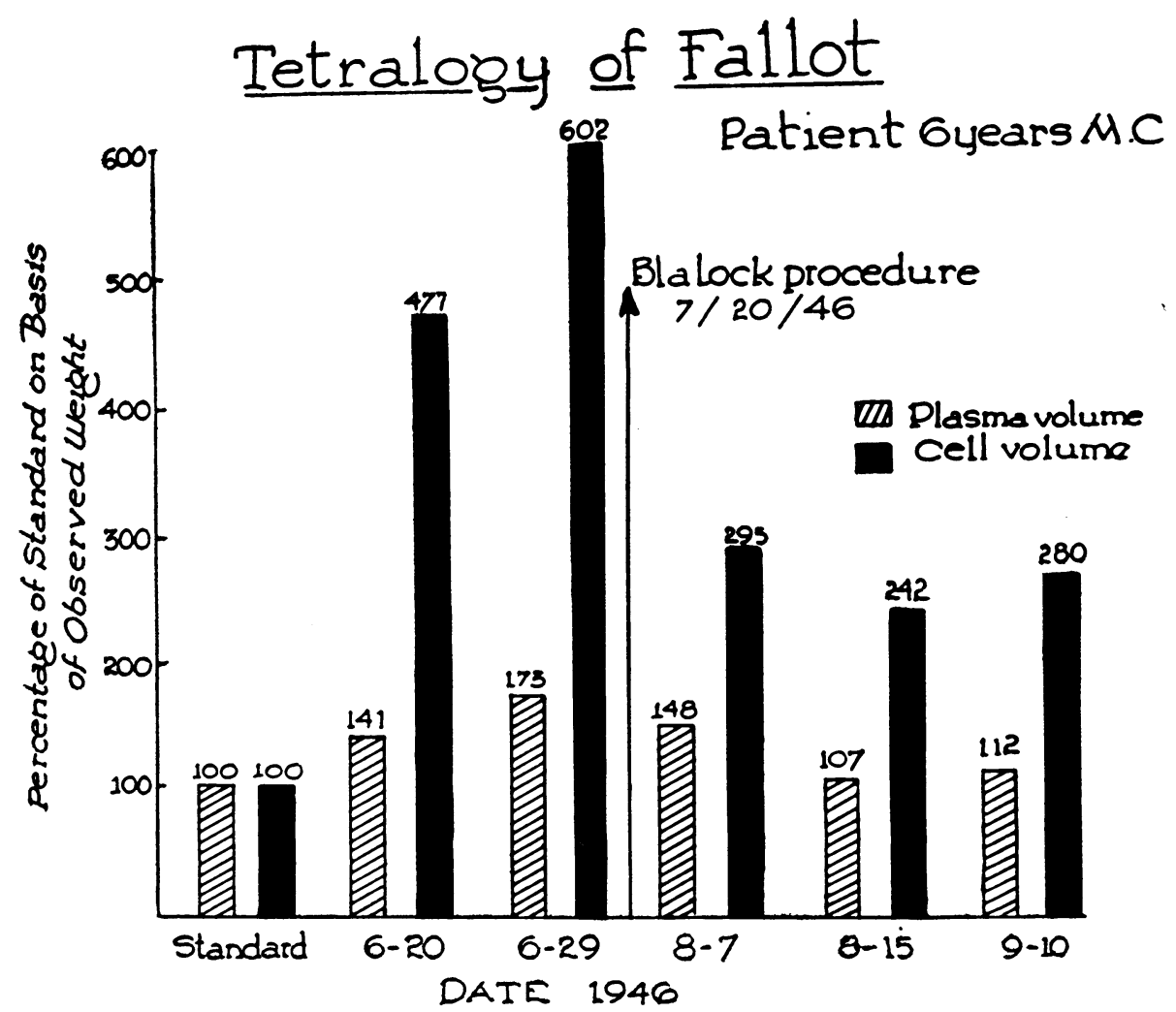

Fig. 3. Serial Determinations of Plasma and Cell Volumes in a Patient 6 Years uf Age (M. C.) with Tetralogy of Fallot 
shown definite improvement. Determinations made postoperatively in Case 211 showed a progressive decline in the total red cell volumes. The total blood volume 1 month after operation was only moderately increased over the standard level for the patient's observed weight but showed a slight rise following resumption of normal activity (Figure 3).

As in the tetralogy, the values for plasma volume in other types of congenital anomalies show variations which are near or slightly above predicted standard values, except for the case of patent ductus arteriosus (Case 213) and of congenital mitral stenosis (Case 215). In the latter cases, the values were $79.8 \mathrm{ml}$. per $\mathrm{kgm}$. and $109.0 \mathrm{ml}$. per kgm., respectively, which are 189 and 259 per cent of standard on an observed, and 140 and 229 per cent of standard on an optimal, weight basis. Case 215, of congenital mitral stenosis, was in probable congestive failure preceding and at the time of the determinations.

In contrast to the findings in the tetralogy, however, only 3 cases showed high total red cell volumes. Again, the patent ductus arteriosus and congenital mitral stenosis show relatively high values (48.8 and $63.9 \mathrm{ml}$. per $\mathrm{kgm}$.). The 3rd exception, isolated pulmonic stenosis, was the only case in which the relationship of high red cell (72 $\mathrm{ml}$. per kgm.) and relatively standard plasma volume ( $44.1 \mathrm{ml}$. per $\mathrm{kgm}$.) simulated that found in the tetralogy.

For the most part, the relative levels of plasma protein were within the standard range, as were the calculated values for total circulating plasma protein. Analysis of the data from the admittedly small number of cases fails to show any significant correlations between the total blood volume, red cell volume, total circulating hemoglobin or total circulating plasma protein and the hemoglobin percentage and hematocrit.

\section{DISCUSSION}

The findings in this study lend support to the point of view that the increased cell volume seen in the tetralogy of Fallot is due to a compensatory stimulation of the bone marrow consequent to the anoxia resulting from inadequate aeration of the circulating blood. Of the 3 prominent factors which might play a part in the development of the anoxemia, it is evident from our data that the septal defect is the least important. Thus, 2 of the cases of isolated septal defect (Nos. 221 and 223) showed significantly low hemoglobin and total cell volumes, one case (No. 222) showed approximately standard values, while the levels in the 4th case (No. 220) were only mildly elevated. The dextroposition of the aorta, on the other hand, must be considered as a possible factor, since it results in mixing of unaerated blood from the right side with aerated blood from the left ventricle. Blalock (19) has experimentally produced a similar mixing by a pulmonary arteriovenous anastomosis following lobectomy in the dog which led to anoxemia and polycythemia.

The most important factor in the production of the anoxemia and the compensatory polycythemia and hypervolemia, as seen in the tetralogy of Fallot, is probably the presence of pulmonic stenosis. This impedes the flow of venous blood into the pulmonic artery and forces the blood to pass into the systemic circulation. Talbott and his colleagues (20) have estimated that 75 per cent of the blood circulating through the heart may not go through the lungs. In addition, the increase in viscosity is a striking feature in the tetralogy of Fallot. We found, as did Talbott and his colleagues, that the blood was so viscous that it was withdrawn only with difficulty. This must impose a real burden upon the myocardium.

The combined action of these various factors results in a chronic anoxemia which resembles that seen in residence at high altitudes (21). The resulting polycythemia and hypervolemia are, in general, conditioned by the degree, duration, and continuity of the anoxic stimulus. As long as there is a marked discrepancy between the demands for oxygen by the tissues and the amount of oxygen furnished to them by the circulating blood, the stimulus continues to operate and the level of circulating red blood cells remains high. In spite of the increased hemoglobin level, the oxygen saturation in many patients is at a critical level of about 60 per cent. At this level, which corresponds to an oxygen saturation similar to that seen at an altitude of 4 miles, the margin of safety is small (19 and 20). The stimulus will be weakened when either the demand for oxygen is decreased or the supply increased. Prolonged bed rest thus 
leads to a lessening of the stimulus and a decrease in the polycythemia. Likewise, the improvement in blood flow to the lungs and consequent increase in the oxygen supply to the tissues brought about by the Blalock procedure results in a decrease in the stimulus and in the polycythemia. The absence of significant polycythemia and hypervolemia in the Eisenmenger complex (Case 210) is to be expected on this basis, since in this patient much less venous blood passes into the aorta directly or by way of the septal defect; a greater portion enters the relatively wide orifice of the pulmonary artery to be oxygenated by the lungs; less cyanosis is observed, and in general the cardiodynamics more nearly approach the normal. In the same manner, no marked polycythemia or hypervolemia is found in patients with ventricular septal defects (Cases $220,221,222$, and 223 ), since there is no flow of blood from the right to the left ventricle unless left ventricular failure is present. These patients, therefore, do not have arterial undersaturation and there is no stimulus to bone marrow from anoxemia. It is difficult to reconcile the finding of an increased red cell volume in isolated pulmonic stenosis (Case 209) with the fact that the arterial blood would not be expected to be undersaturated in this condition. However, the similarity of the plasma and cell volume changes in our cases of isolated pulmonic stenosis and Fallot's tetralogy suggests a possible similar etiological basis for the hypervolemia in these 2 diseases. We cannot explain the increase in plasma and cell volume in the case of patent ductus arteriosus.

The fact that the chronic anoxemia of the tetralogy of Fallot does not modify the erythropoietic activity permanently is of interest. Hurtado, Merino, and Delgado (21) have shown that normal individuals who have lived since birth at high altitudes and are brought down to sea level, show after some time, blood characteristics similar to those found in normal individuals who have always lived at sea level. Similarly, decrease of the anoxemia in patients with tetralogy by bed rest or the Blalock procedure results in a gradual change towards the blood picture found in the so-called "normal" individual. The fate of the red blood cells involved in this decrease awaits further study. The relatively gradual change and the absence of clinical icterus suggests that the superfluous red cells already in circulation are being destroyed while fewer red cells are being elaborated by the bone marrow.

The effectiveness of the polycythemia in the tetralogy seems to lie in the fact that it enables the patient to meet his resting needs for oxygen although it may not provide for much margin of safety. The large volume of viscous blood, however, imposes a rather severe strain on the heart which usually eventuates in congestive heart failure in the patient surviving to the 3 rd or 4 th decade, as cardiac reserve diminishes.

These studies are being continued. It would seem desirable to know much more about the underlying physiological adaptations of the circulation and respiration in congenital heart disease. Since among the most marked changes are those which occur in red cell volume, it would be of value to check further the validity of the dyehematocrit method in these conditions by the carbon monoxide or radioactive-iron techniques. The material gathered to date, however, indicates the possible usefulness of blood volume determinations in supplementing the usual tests for the differentiation of the various types of congenital heart disease. The presence of an absolute erythrocytosis, as indicated by a significant increase in red cell volume without significant change in the plasma volume, should be interpreted as suggestive of the presence of pulmonic stenosis. The serial determination of the blood volume and total circulating hemoglobin should also serve as a valuable aid in indicating the optimal time for surgery and as a measure of the beneficial effects of surgical procedures.

\section{CASE REPORTS}

\section{No. 208, W. M., 22 years}

This patient gave a history of having been blue and having had clubbing of the fingers and curved nails since early childhood. Relatives stated he had been blue since birth. He had severe dyspnea and many dizzy and fainting spells occurring on slight exertion. He had an acute thrombophlebitis followed by chronic leg edema and ulceration in 1943. This responded well to treatment consisting of elimination of arterio-spasm by lumbar sympathetic blocks and compression dressings of elastic bandage or Unna's paste. In 1945 a high-low ligation for superficial varicosities was done on the right, after which the low incision healed very slowly. He was also admitted on one occasion with a diagnosis of "psychotic personality" and "gastric neurosis." 
Physical examination on various admissions showed a fairly well developed adult white male. The skin was of a dusky blue color particularly marked in the ears and face. On exertion the cyanosis became more intense. No resting dyspnea was present, but exertional dyspnea was marked. Three-plus clubbing of the fingers and watch-crystalling of the nails was present. Examination of the chest revealed a loud precardial systolic murmur maximal over the pulmonic area. A systolic thrill over the same area was present. A 6-foot heart plate showed a pulmonary conus concavity and a small aortic knob. Electrocardiogram showed pronounced right axis deviation, and cardiography showed delay in right ventricle emptying. The aortic arch and descending aorta were demonstrated to be on the left when barium was introduced into the esophagus. Circulation time arm-totongue was 7 seconds with calcium gluconate. Determination of circulation time with ether in this patient resulted in a measurement of arm-to-face circulation time of 3.1 seconds as evidenced by severe burning of the face. The failure of this patient to smell the ether at any time after injection suggests that the amount of blood going to his lungs was very small as compared to his total blood volume. Arterial oxygen content was 18.35 per cent and venous 11.29 per cent. Venous oxygen capacity was 27.28 per cent. Venous pressure was $132 \mathrm{mms}$. of citrate; R.B.C.'s varied from 8 to 10 million. Other blood findings are given in Table I and Figure 2. Liver and kidney function tests were normal.

Treatment with semi bed rest from January to March, 1946, resulted in some improvement in exertional dyspnea and cyanosis, and resting cyanosis diminished. Attempted anastomosis of the right subclavian-pulmonary artery on May 9, 1946, by Dr. Alton Ochsner, was unsuccessful because of the relative shortness of the subclavian artery. Following 6 weeks of intermittent right carotid compression, anastomosis of the right common carotid-right pulmonary artery by the Blalock method was performed by Dr. Ochsner. Following this, the patient's cyanosis diminished for a few hours. He developed a left hemiplegia, however, and expired on the 3rd postoperative day.

\section{No. 211, M. C., 6 years}

The essential history on this boy, obtained from his mother, was that he had been blue since birth. The blueness was intensified by even slight exertion. He became short of breath upon slight exertion and as he became older had "falling out" spells, on attempting exercise, such as running or climbing stairs. His mental development was normal and his physical development somewhat retarded. Positive physical findings were: (1) moderately underweight; (2) increased duskiness of face, ears, lips, finger-nails, markedly exaggerated on crying ; (3) marked clubbing and watch-crystalling of fingers and toes; (4) loud precordial systolic murmur maximal over pulmonic area; (5) right axis deviation and sinus tachycardia on E.C.G.; and (6) R.B.C. of 6 to 8 million.

This patient was observed and treated with bed rest for a period of 2 months, during which time there was no change except questionably slight improvement of his exertional dyspnea. He, at no time, had findings suggestive of congestive failure. On July 23, 1946, a Blalock type anastomosis was done by Dr. Ochsner between the right subclavian and the right pulmonary artery. Immediate slight improvement in cyanosis resulted at this time. Little blood having been lost during the operation, it was thought advisable, in order to decrease the blood viscosity and because of danger of clotting, to withdraw $150 \mathrm{ml}$. of blood. Withdrawal of this amount caused the patient to go into severe secondary shock which was quickly overcome by re-administration of the blood.

The patient's convalescence was uneventful. Only a trace of finger and toe clubbing and watch-crystalling remains. At present he has no resting cyanosis and only slight exertional cyanosis. His exercise tolerance is much improved, his blood volume has dropped as previously noted (Figure 1). However, no murmur except the previously present pulmonic murmur can be heard.

The prompt secondary shock sustained by this patient when, following Blalock's suggestion (19), $150 \mathrm{ml}$. of blood was withdrawn postoperatively, raises the question as to the desirability of bleeding in these cases. There seems to be no reason to anticipate a sudden shrinkage of the vascular capacity so as to produce increased viscosity and clotting. In fact, as Blalock has reported and we have found, the changes towards "normal" occur gradually over a period of weeks. It is more likely that the trauma of the relatively long operation produces a widespread dilatation and temporary enlargement of the vascular bed, which certainly provides an adequate factor of safety during the early postoperative period.

\section{SUMMARY}

1. Plasma, red cell, and total blood volumes, total circulating hemoglobin, and plasma protein were studied in 7 cases of the tetralogy of Fallot, 4 cases of isolated interventricular septal defect, and 1 case each of probable Eisenmenger complex, isolated pulmonary stenosis, coarctation of the aorta, congenital mitral stenosis, and patent ductus arteriosus.

2. All patients with tetralogy of Fallot and the case of pulmonic stenosis showed a markedly increased blood volume due primarily to an increase in total red cell volume. Hematocrit and hemoglobin levels were also high. Plasma volume was at, or slightly above, standard levels.

3. Bed rest and production of a new shunt by the Blalock procedure in 2 cases resulted ${ }^{*}$ in a gradual decrease of red cell volume toward standard values.

4. Blood volume was at approximately standard levels in the cases of interventricular septal defect, Eisenmenger complex, and coarctation of the 
aorta. The cases of congenital mitral stenosis and patent ductus arterioșus showed high blood volumes due to increases in plasma volume as well as red cell volume.

We are grateful to Miss Genie Burt and Dr. Blanche Jackson for their assistance and to Drs. V. Platou and Clarence T. Rae for their cooperation. The patients were hospitalized at Charity Hospital and Touro Infirmary.

\section{BIBLIOGRAPHY}

1. Blalock, A., and Taussig, H. B., Surgical treatment of malformations of heart in which there is pulmonary stenosis or pulmonary atresia. J. A. M. A., 1945, 128, 189.

2. Fallot, A., Contribution à l'anatomie Pathologique de al Maladie Bleue (cyanose cardiaque). Marseille Med., 1888, 25, 77, 138, 207, 270, 341, 403.

3. Abbott, Maude E. Atlas of Congenital Cardiac Disease. Am. Heart Assoc., New York, 1936, p. 60.

4. Glazebrook, A. J., Eisenmenger's complex. Brit. Heart J., 1943, 5, 147.

5. White, P. D., and Sprague, H. B., Tetralogy of Fallot; report of case in noted musician, who lived to his sixtieth year. J. A. M. A., 1929, 92, 787.

6. Meyer, P., Hamodynamik und Hamophysikochemie bein einem Fall von Ventrikelseptumdefekt mit Pulmonalstenose; die Bedeutung der Hamoglobinvermehrung bei Sauerstoffmangel. Ztschr. f. klin. Med., 1932, 120, 341.

7. Blumenfeldt, E., and Wollheim, E., Zur klinischen Beurteilung angeborener Herzfehler. Klin. Wchnschr., 1927, 6, 396.

8. Weber, F. P., and Dorner, G., A case of congenital pulmonary stenosis, with special consideration of the nature of the secondary blood changes. Lancet, $1911,1,150$.

9. Hallock, P., Polycythemia of morbus caeruleus (cyanotic type of congenital heart disease). Proc. Soc. Exper. Biol. \& Med., 1940, 44, 11.

10. Gregersen, M. I., Practical method for determination of blood volume with dye-T-1824; survey of present basis of dye-method and its clinical applications. J. Lab. and Clin. Med., 1944, 29, 1266.

11a. Chapin, M. A., and Ross, J. F., Determination of true cell volume by dye dilution, by protein dilution, and with radioactive iron. Error of centrifuge hematocrit. Am. J. Physiol., 1942, 137, 447.

b. Lawson, H. C., Rappaport, D. B., and Ramirez, A., The recovery of injected dye and the yield of blood cells by perfusion of the cardiovascular system in barbitalized dogs. Am. J. Physiol., 1946, 147, 412. c. Stead, E. A., Jr., and Ebert, R. V., Relationship of plasma volume and cell plasma ratio to total red cell volume. Am. J. Physiol., 1941, 132, 411.

d. Gibson, J. G., II, Weiss, S., Evans, R. D., Peacock, W. C., Irvine, J. W., Jr., Good, W. M., and Kip, A. F., The measurement of the circulating red cell volume by means of two radioactive isotopes of iron. J. Clin. Invest., 1946, 25, 616.

12. Root, W. S., Roughton, F. J. W., and Gregersen, $\mathbf{M}$. I., Simultaneous determination of blood volume by $\mathrm{CO}$ and dye $(\mathrm{T}-1824)$ under various conditions. Am. J. Physiol., 1946, 146, 729.

13. Evelyn, K. A., Stabilized photoelectric colorimeter with light filters. J. Biol. Chem., 1936, 115, 63.

14. Barbour, H. G., and Hamilton, W. F., Falling drop method for determining specific gravity; clinical applications. J. A. M. A., 1927, 88, 91.

15. Weech, A. A., Reeves, E. B., and Goettsch, E., Relationship between specific gravity and protein content in plasma, serum, and transudate from dogs. J. Biol. Chem., 1936, 113, 167.

16a. Davis, L. J.: Determination of blood volume in man with Evans blue ("T-1824"). Edinburgh M. J., 1942, 49, 465.

b. Gibson, J. G., Jr., and Evans, W. A., Jr., Clinical studies of blood volume; relation of plasma and total blood volume to venous pressure, blood velocity rate, physical measurements, age, and sex in 90 normal humans. J. Clin. Invest., 1937, 16, 317.

c. Stewart, J. D., and Warner, F., Observations on severely wounded in forward field hospitals, with special reference to wound shock. Ann. Surg., 1945, $122,129$.

d. Taylor, H. L., Erikson, L., Henschel, A., and Keys, A., Effect of bed rest on blood volume of normal young men. Am. J. Physiol., 1945, 144, 227.

17. Brines, J. K., Gibson, J. G., Jr., and Kunkel, P., Blood volume in normal infants and children. J. Pediat., 1941, 18, 447.

18. Wintrobe, M. M., Clinical Hematology. Lea and Febiger, Philadelphia, 1942.

19. Blalock, A., Effects of an artificial ductus arteriosus on experimental cyanosis and anoxemia. Arch. Surg., 1946, 52, 247.

20. Talbott, John H., Coombs, F. S., Castleman, B., Chamberlain, F., Consolazio, W. V., and White, P. D., Record case of tetralogy of Fallot, with comments on metabolic and pathologic studies. Am. Heart J., 1941, 22, 754.

21. Hurtado, A., Merino, C., and Delgado, E., Influence of anoxemia on hemopoietic activity. Arch. Int. Med., 1945, 75, 284. 